\title{
プレキャストコンクリートの環境負荷低減策 に関する検討
}

河合研至 $*^{1} \cdot$ 藤木昭宏 $*^{2} \cdot$ 赤崎大希 $*^{3} \cdot$ 徳久陽一 $*^{4}$

\begin{abstract}
概要 : 構造物設計の際には構造性能や耐久性能が重視されており, $\mathrm{CO}_{2}$ 排出量などの環境性能が考慮されることは少 ない。そこで本研究ではプレキャストコンクリート（以下 PCa）製品に着目し，ある PCa 製品製造の環境負荷評価 を行った上で, 廃棄物や産業副産物, 再生骨材をコンクリート用材料として使用寸ることと, 蒸気養生を気温の高い 日に限り行わないことで，環境負荷低減の観点からより有用な $\mathrm{PCa}$ 製品を製造する方策の検討を行った。その結果， 本研究で対象とした PCa 製品工場では年間 45.7 日間蒸気養生を行わないことで $\mathrm{SO}_{\mathrm{x}}$ 排出量を約 $14 \%$ 低減でき, フラ イアッシュを $20 \%$ ，細骨材の $30 \%$ を溶融スラグ細骨材に置換することで $\mathrm{CO}_{2}$ 排出量を約 $18 \%$ 低減できた。 キーワード : 環境負荷, プレキャストコンクリート, 再生骨材, 蒸気養生
\end{abstract}

\section{1. はじめに}

現在, 地球温暖化, 酸性化, 海洋污染等の環境問題の深 刻化が世界中で叫ばれており, 環境負荷低減への取り組み が緊急の課題となっている。そのため, 各産業において環 境負荷低減の努力が必要であり，そのことは建設産業にお いても同様であり，無視できない問題となっている。建設 産業においてコンクリート構造物を設計する際, 而久性, 安全性, 使用性などの照査が行われるが, 環境負荷物質排 出量といった環境性能については要求性能が明確でないケ ースが多く, 同様なレベルで照査することは現状では困難 である。しかし, 今後より一層, 環境負荷低減のニーズが 高まり, 要求性能が明確に示されるケースが増えてくると 予想される。

そこで本研究では，建設活動を行う際に必要不可欠なコ ンクリート製品の中でもプレキャストコンクリート（以下， PCa）製品に着目し，環境性能の評価を行った。本研究で PCa 製品に着目した理由は，PCa 製品は工場で製品化され るため, 現場周辺環境の影響を受けにくく, レディーミク ストコンクリートを用いた場合に比べて迅速な品質の確認 と安定した品質の確保が期待でき, 環境負荷低減を図るた めに，コンクリート材料として産業廃棄物や産業副産物を 使用した場合も，一定品質の確保が期待できると考えられ るからである。また, PCa 製品は製品自体が JIS 規格を満
たすことで力学性能を満足するため, レディーミクストコ ンクリートに比べて要求性能の中で環境性能を考慮しやす いと言える。

以上の理由より, 本研究では PCa 製品に着目して, ある $\mathrm{PCa}$ 製品会社の 9 工場に対するヒアリング調査結果をもと に, PCa 製品の製造における環境負荷評価を行った上で, 環境負荷低減の方策について検討を行った。方策は，環境 負荷物質排出量の低減に力点を置いた低環境負荷型 $\mathrm{PCa}$ と 解体コンクリートの有効活用に力点を置いた高リサイクル 型PCaについて検討した。

\section{2. 調査概要}

\section{1 環境負荷評価範囲}

$\mathrm{PCa}$ 製品のライフサイクルは一般的にセメントや骨材な ど原材料の製造から始まり, 原材料の $\mathrm{PCa}$ 製品工場への運 搬, PCa 製品工場での製品化, PCa 製品の現場への運搬, 現場での PCa 製品の施工，供用・維持管理，供用期閒終了 後の解体, 廃棄もしくは再利用となっている。本研究では このライフサイクルのうち，原材料の製造において排出さ れる環境負荷を原材料起源の環境負荷とし，PCa 製品工場 での製品化における環境負荷を製品化起源の環境負荷とし， この 2 つ起源における環境負荷を評価対象とした。原材 料の製造や PCa製品工場での製品化において排出される環

\footnotetext{
*1 広島大学教授 大学院工学研究院社会環境空間部門 工博 （正会員） $\bar{T} 739-8527$ 広島県東広島市鏡山 1-4-1

*2 ランデス (株) 研究所 博 (工) （正会員） テ719-3192 岡山県真庭市開田 630-1

*3 広島大学大学院工学研究科（学生会員）７７39-8527 広島県東広島市鏡山 $1-4-1$

*4 広島大学大学院工学研究科 $\quad$ T739-8527 広島県東広島市鏡山 1-4-1
} 
境負荷は，工場の場所や立地条件にあまり影響されず，日 本全国の PCa 製品製造において共通して言及できるが，運 搬や現場での PCa 製品の施工, 供用において排出される環 境負荷は, PCa 製品工場や施工現場の場所や立地条件によ って排出量が大きく左右されるため本研究では検討対象か ら除外した。本研究で評価対象とした原材料の製造におけ る環境負荷とは，原材料を製造する際に石炭，石油，石灰 石，粘土，骨材資源，石膏といった天然資源，エネルギー が消費され, セメントや細骨材, 粗骨材が製造されるが, その結果排出される環境負荷を指す。また, PCa 製品工場 での製品化における環境負荷とは, PCa 製品工場における 型枠組立て, コンクリート練混ぜ, 打込み, 蒸気養生とい った各工程で消費される電力, 軽油, 重油に関して排出さ れる環境負荷を指す。

\section{$2.2 \mathrm{PCa}$ 製品の概要}

本研究では, PCa 製品製造における環境負荷評価を行う ために PCa 製品工場にヒアリング調査を行った。調査対象 とした PCa 製品工場は中国地方に立地し, 年間製造量約 40,000t (約 $13,000 \mathrm{~m}^{3}$ ) であり, 擁壁, 水路, 道路など様々 な用途で用いられる水結合材比 $25 \sim 40 \%$ で設計基準強度 30〜 70 N/mm $\mathrm{mm}^{2}$ の数種類のコンクリート配合を使用している。 調査の結果, 各種コンクリート配合と製造量および工場内 での電力, 軽油, 重油使用量を得た。また, 調査を行った $\mathrm{PCa}$ 製品工場ではコンクリート打設後 15 時間, 設定温度 $60^{\circ} \mathrm{C}$ の蒸気養生を行った上で, 材齢 1 日で脱型, 以後気中 暴露を行い，材齢 7 日以上で製品として出荷可能としてい る。

\subsection{PCa 製品の環境負荷評価}

本研究では, ヒアリング調査を行った工場から出荷され る $\mathrm{PCa}$ 製品に関する環境負荷評価を行った。環境負荷評価 は，ヒアリング調査で得た各材料や燃料使用量に環境負荷 の原単位 ${ }^{1)}$ を乗じることで行われる。本研究での環境負荷 評価項目は $\mathrm{CO}_{2}, \mathrm{SO}_{\mathrm{X}}, \mathrm{NO}_{\mathrm{X}}$, ばいじん排出量とした。表 -1 , 表一2に環境負荷原単位であるインベントリデータを 示す。また， 2.2 で言及のとおり，本研究で調査を行った PCa 製品工場では数種類のコンクリート配合が用いられて いるが，計算の簡易化と単純化のため，代表的な配合を基 本配合と設定し，PCa 製品工場の年間製造量全てが基本配 合の製品であったと仮定して環境負荷を算出した。ここで, 基本配合と設定した配合は様々な製品に対して用いられ， 工場内で全製造量の約 34\%を占める配合である。なお，各 種配合にそのそれぞれの製造量を乗じた和を全製造量で除 して算出した PCa 製品工場での平均材料使用量と, 基本配 合の材料使用量では, 例えば平均セメント使用量が $440.3 \mathrm{~kg} / \mathrm{m}^{3}$ であるのに対し，基本配合のセメント使用量が $433 \mathrm{~kg} / \mathrm{m}^{3}$ となり大きな差はなかったため, 全製造量が基本 配合を用いたものと仮定した場合にも厳密に試算を行った 場合と大きな差は生じず, 調査を行った PCa 製品工場内で は基本配合は一般的な配合であると考えた。環境負荷評価 は原材料起源と製品化起源に分けて行い，その和を $\mathrm{PCa}$ 製 品製造における環境負荷とした。表一3 に基本配合を，表 -4 に PCa 製品工場における年間の各種燃料消費量をそれ ぞれ示す。

表一1 本研究で使用したインベントリデータ ${ }^{1)}$

\begin{tabular}{|c|c|c|c|c|c|c|}
\hline 材料名 & 記号 & $\begin{array}{l}\mathrm{CO}_{2} \text { 排出量 } \\
\left(\mathrm{kg}-\mathrm{CO}_{2} / \mathrm{t}\right)\end{array}$ & $\begin{array}{l}\mathrm{SO}_{\mathrm{X}} \text { 排出量 } \\
\left(\mathrm{kg}-\mathrm{SO}_{\mathrm{X}} / \mathrm{t}\right)\end{array}$ & $\begin{array}{l}\mathrm{NO}_{x} \text { 排出量 } \\
\left(\mathrm{kg}-\mathrm{NO}_{x} / \mathrm{t}\right)\end{array}$ & $\begin{array}{c}\text { ばいじん排出量 } \\
(\mathrm{kg}-\mathrm{PM} / \mathrm{t})\end{array}$ & $\begin{array}{c}\text { リサイクル } \\
\text { (wet-kg/t) }\end{array}$ \\
\hline ポルトランドセメント & C & 766.6 & $1.22 \mathrm{E}-01$ & $1.55 \mathrm{E}+00$ & $3.58 \mathrm{E}-02$ & 148 \\
\hline 粗骨材 & $G$ & 2.9 & $6.07 E-03$ & $4.15 E-03$ & $1.41 E-03$ & - \\
\hline 細骨材 & $S$ & 3.7 & $8.60 E-03$ & $5.86 E-03$ & $1.99 E-03$ & - \\
\hline 溶融スラグ骨材（電気式） & $\mathrm{ms}$ & 430.3 & $1.23 E-01$ & $1.50 E-01$ & $2.49 E-02$ & 1238 \\
\hline フライアッシュ & FA & 19.6 & $6.20 E-03$ & $7.54 E-03$ & $1.25 E-03$ & - \\
\hline
\end{tabular}

斜体字は電力起源しか考慮していないもの（プロセス起源は不明）

wet-kg とは, 水分を含んだ状態での質量であることを表している

表一2 本研究で使用したインベントリデータ 1)

\begin{tabular}{|c|c|c|c|c|c|}
\hline 材料名 & $\begin{array}{c}\text { 単位 } \\
(*)\end{array}$ & $\begin{array}{c}\mathrm{CO}_{2} \text { 排出量 } \\
\left(\mathrm{kg}-\mathrm{CO}_{2} / *\right)\end{array}$ & $\begin{array}{c}\mathrm{SO}_{\text {X排出量 }} \\
\left(\mathrm{kg}-\mathrm{SO}_{\mathrm{X}} / *\right)\end{array}$ & $\begin{array}{c}\mathrm{NO}_{\mathbf{X}} \text { 排出量 } \\
\left(\mathrm{kg}-\mathrm{NO}_{\mathbf{X}} / *\right)\end{array}$ & $\begin{array}{c}\text { ばいじん排出量 } \\
(\mathrm{kg}-\mathrm{PM} / *)\end{array}$ \\
\hline 軽油 & $\mathrm{L}$ & 2.64 & $2.04 E-03$ & $3.96 E-02$ & $2.01 E-03$ \\
\hline $\mathrm{A}$ 重油 & $\mathrm{L}$ & 2.77 & $1.30 E-02$ & $2.38 . E-03$ & $3.00 . E-03$ \\
\hline 購入電力 & $\mathrm{kWh}$ & 0.41 & $1.30 E-04$ & $1.60 E-04$ & $3.00 E-05$ \\
\hline
\end{tabular}

斜体字は電力起源しか考慮していないもの（プロセス起源は不明）

各排出量における単位の分母 $(*)$ は，各分類の単位欄に示す単位がその位置に入ることを示す

重油は動粘度により,「A 重油」「B 重油」「C 重油」に分類されており，本研究では「A 重油」のデータを使用した 
表一3 設定した基本配合

\begin{tabular}{|c|c|c|c|c|c|c|c|c|}
\hline $\begin{array}{c}\text { 設計基準強度 } \\
\left(\mathrm{N} / \mathrm{mm}^{2}\right)\end{array}$ & \multirow{2}{*}{ W/C } & \multirow{2}{*}{ Air $(\%)$} & \multirow{2}{*}{$\mathrm{s} / \mathrm{a}$} & \multicolumn{5}{|c|}{ 単位量 $\left(\mathrm{kg} / \mathrm{m}^{3}\right)$} \\
\cline { 5 - 8 } & & & & W & C & $\mathrm{S}$ & $\mathrm{G}$ & $\mathrm{Ad}$ \\
\hline 35.0 & 0.40 & 4.5 & 0.4 & 173 & 433 & 689 & 1081 & 1.61 \\
\hline
\end{tabular}

表一4 PCa 製品工場における年間燃料消費量

\begin{tabular}{|c|c|c|}
\hline & 単位 & 使用量 \\
\hline 電気使用量 & $\mathrm{kWh} /$ year & 539,994 \\
\hline 重油使用量 & L/year & 276,400 \\
\hline 軽油使用量 & L/year & 22,810 \\
\hline
\end{tabular}

表 -5 原材料製造に関する $\mathrm{CO}_{2}$ 排出量（基本配合）

\begin{tabular}{|c|c|c|c|c|c|c|}
\hline 材料名 & $\begin{array}{l}\text { 単位量 } \\
\left(\mathrm{kg} / \mathrm{m}^{3}\right)\end{array}$ & $\begin{array}{c}\mathrm{CO}_{2} \text { 排出量原単位 } \\
\left(\mathrm{kg}^{-}-\mathrm{CO}_{2} / \mathrm{t}\right)\end{array}$ & 製造量 $\left(\mathrm{m}^{3}\right)$ & $\begin{array}{c}\mathrm{CO}_{2} \text { 排出量 } \\
\left(\mathrm{kg}-\mathrm{CO}_{2}\right)\end{array}$ & $\begin{array}{c}\mathrm{CO}_{2} \text { 排出量 } \\
\left(\mathrm{t}-\mathrm{CO}_{2}\right)\end{array}$ & $\begin{array}{l}\text { 合計 } \mathrm{CO}_{2} \text { 排出量 } \\
\left(\mathrm{t}-\mathrm{CO}_{2} \text { year) }\right.\end{array}$ \\
\hline ポルトランドセメント & 433 & 766.6 & 13,000 & $4,315,191$ & 4,315 & \multirow{3}{*}{4,389} \\
\hline $\begin{array}{l}\text { 細骨材 } \\
\end{array}$ & 689 & 3.7 & 13,000 & 33,141 & 33 & \\
\hline 粗骨材 & 1,081 & 2.9 & 13,000 & 40,754 & 41 & \\
\hline
\end{tabular}

表－6 原材料起源の環境負荷（基本配合）

\begin{tabular}{|c|c|c|c|}
\hline $\mathrm{CO}_{2}(\mathrm{t} /$ year $)$ & $\mathrm{SOx}(\mathrm{kg} /$ year $)$ & $\mathrm{NOx}(\mathrm{kg} /$ year $)$ & ばいじん $(\mathrm{kg} /$ year $)$ \\
\hline 4,389 & 849 & 8,836 & 239 \\
\hline
\end{tabular}

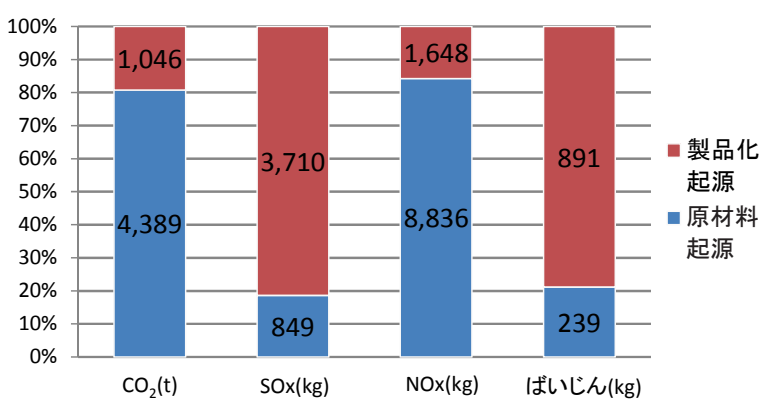

図-1＼cjkstart環境負荷の排出割合

\section{4 原材料起源亡製品化起源の環境負荷評価}

原材料起源の環境負荷は, 各原材料使用量にインベント リデータを乗じて, それらの和をとることで算出される。 各原材料使用量はコンクリート配合 $\left(\mathrm{kg} / \mathrm{m}^{3}\right)$ に製造量 $\left(13,000 \mathrm{~m}^{3}\right)$ を乗じることで算出される。環境負荷物質排 出量の算出例として, 基本配合における $\mathrm{CO}_{2}$ 排出量の算出 を表一 5 に示す。また, 基本配合における原材料製造に関 する各環境負荷物質排出量の算出結果を表一6に示す。製 品化起源の環境負荷も同様に重油と軽油, 電力消費量にイ ンベントリデータを乗じて, それらの和をとることで算出 される。製品化起源の各環境負荷の算出結果を表一7に示 す。

\section{$2.5 \mathrm{PCa}$ 製品製造に関する環境負荷評価}

$\mathrm{PCa}$ 製品製造に関する環境負荷は, 上記の原材料起源と 製品化起源の環境負荷の和である。原材料起源と製品化起 源の $\mathrm{CO}_{2}, \mathrm{SO}_{\mathrm{X}}, \mathrm{NO}_{\mathrm{X}}$, ばいじん排出量の排出割合を図ー1 に示す。図一 1 より, $\mathrm{CO}_{2}$ 排出量と $\mathrm{NO}_{\mathrm{X}}$ 排出量は原材料起 源がそれぞれ約 $81 \%$ と約 $84 \%$ で大部分を占め, $\mathrm{SO}_{\mathrm{X}}$ 排出量 とばいじん排出量は製品化起源がそれぞれ約 $81 \%$ と約 79\%で大部分を占める結果となった。
表-7 製品化起源の環境負荷

\begin{tabular}{|c|c|c|c|}
\hline $\mathrm{CO}_{2}(\mathrm{t} /$ year $)$ & $\mathrm{SOx}(\mathrm{kg} /$ year) & $\mathrm{NOx}(\mathrm{kg} /$ year $)$ & ばいじん(kg/year) \\
\hline 1,046 & 3,710 & 1,648 & 891 \\
\hline
\end{tabular}

\section{3. 低環境負荷型 $\mathrm{PCa}$ の提案}

\section{1 実験概要}

$\mathrm{PCa}$ 製品製造の環境負荷低減を図る場合，原材料起源の 面からは使用する原材料をより低環境負荷の原材料に置 換すること, 製品化起源の面からは PCa 製品工場で使用す る燃料消費量を減らすことの 2 種類の方法が考えられる。 そこで本研究では PCa 製品を製造する際に, 細骨材の一部 を溶融スラグ細骨材（電気式，密度 $2.83 \mathrm{~g} / \mathrm{cm}^{3}$, 吸水率 $0.32 \%$ ）に，粗骨材の一部を再生粗骨材（再生粗骨材 $\mathrm{M}$, 密度 $2.45 \mathrm{~g} / \mathrm{cm}^{3}$, 吸水率 $5.05 \%$ ）に，セメントの一部をフラ イアッシュ（密度 $2.2 \mathrm{~g} / \mathrm{cm}^{3}$ ) に置換すること, さらに気温 の高い日に限り PCa 製品製造の際の蒸気養生を行わない ことで環境負荷の低減を図った。図ー1の結果より, 原材 料起源の環境負荷を低減できれば特に $\mathrm{CO}_{2}$ 排出量と $\mathrm{NO}_{\mathrm{X}}$ 排出量低減に効果的であり, 製品化起源の環境負荷を低減 できれば特に $\mathrm{SO}_{\mathrm{X}}$ 排出量とばいじん排出量低減に効果的 であると考えられる。

上記の環境負荷低減を図った場合の強度と耐久性に関 する検討を行うために，様々な組合せで原材料置換を行な ったコンクリート供試体を作製した。また，供試体作製時 期は気温の高い 8 月下旬 (平均気温 $25.3 \sim 34.2^{\circ} \mathrm{C}$ ) とし, 全てのコンクリート配合に対して, 打設後蒸気養生を行う 場合と気中暴露する場合の 2 種類の方法でコンクリートを 作製した。強度，耐久性に関寸る検討は，それぞれ圧縮強 度試験，促進中性化試験により行なった。

作製した供試体のコンクリート配合を表ー8に示す。表 -8 の 40NC とは基本配合を示し, FA はフライアッシュ, $\mathrm{ms}$ は溶融スラグ細骨材, ra は再生粗骨材をそれぞれ示す。 また, 配合名は最初の数值が W/B を示し, その後に基本 配合に対する置換材料名と置換率を示している。 
表ー8＼cjkstart環境負荷評価を行った各配合の詳細

\begin{tabular}{|c|c|c|c|c|c|c|c|c|c|c|c|c|c|c|}
\hline \multirow{2}{*}{ 配合名 } & \multicolumn{2}{|c|}{ 圧縮強度 $\left(\mathrm{N} / \mathrm{mm}^{2}\right)$} & \multirow{2}{*}{$\begin{array}{c}\text { slump } \\
(\mathrm{cm})\end{array}$} & \multirow{2}{*}{$\begin{array}{l}\text { Air } \\
(\%)\end{array}$} & \multirow{2}{*}{ W/B } & \multirow{2}{*}{$\mathrm{s} / \mathrm{a}$} & \multicolumn{8}{|c|}{ 単位量 $\left(\mathrm{kg} / \mathrm{m}^{3}\right)$} \\
\hline & $\mathrm{sc}$ & dry & & & & & W & $\mathrm{C}$ & FA & $S$ & $\mathrm{~ms}$ & $\mathrm{G}$ & $\mathrm{ra}$ & $\mathrm{Ad}$ \\
\hline $40 \mathrm{NC}$ & 45.7 & 40.7 & 16.5 & 3.3 & 0.40 & 0.4 & 173 & 433 & - & 689 & - & 1081 & - & 1.52 \\
\hline $35 F A 20$ & 43.0 & 41.2 & 15.5 & 2.9 & 0.35 & 0.4 & 152 & 346 & 87 & 698 & - & 1097 & - & 1.95 \\
\hline $40 \mathrm{~ms} 30$ & 39.9 & 40.9 & 17 & 4.1 & 0.40 & 0.4 & 173 & 433 & 一 & 482 & 227 & 1081 & 一 & 1.52 \\
\hline $37.5 \mathrm{~ms} 50$ & 45.9 & 45.7 & 17.5 & 4.1 & 0.375 & 0.4 & 162 & 433 & 一 & 350 & 385 & 1099 & - & 1.73 \\
\hline $37.5 \mathrm{ra} 100$ & 47.6 & 45.1 & 19 & 3.4 & 0.375 & 0.4 & 162 & 433 & - & 700 & - & - & 1000 & 1.73 \\
\hline 40ra100 & 46.7 & 49.0 & 15.5 & 3.0 & 0.40 & 0.4 & 173 & 433 & - & 689 & - & - & 984 & 1.52 \\
\hline $35 \mathrm{FA} 20 \mathrm{~ms} 30$ & 38.5 & 36.2 & 15.5 & 3.1 & 0.35 & 0.4 & 152 & 346 & 87 & 489 & 231 & 1097 & 一 & 1.73 \\
\hline 35FA20ra100 & 41.4 & 36.8 & 15.5 & 2.8 & 0.35 & 0.4 & 152 & 346 & 87 & 698 & - & - & 999 & 1.73 \\
\hline
\end{tabular}

表中の FA はフライアッシュ, ms は溶融スラグ細骨材, ra は再生粗骨材を示す

$\mathrm{sc}$ とは打設後 15 時間, 最大 $60^{\circ} \mathrm{C}$ で蒸気養生を行ない, 材齢 1 日で脱型し以後気中暴露, dry とは打設後気中暴露し材齢 1 日で脱型, 以 後再び気中暴露した供試体である

打設時期が 8 月下旬であったため, 気中暴露の際は温度約 $25 \sim 35^{\circ} \mathrm{C}$, 相対湿度は約 $45 \sim 90 \%$, 平均 $72 \%$ あった

表中の圧縮強度は材齢 7 日の試験結果を示す

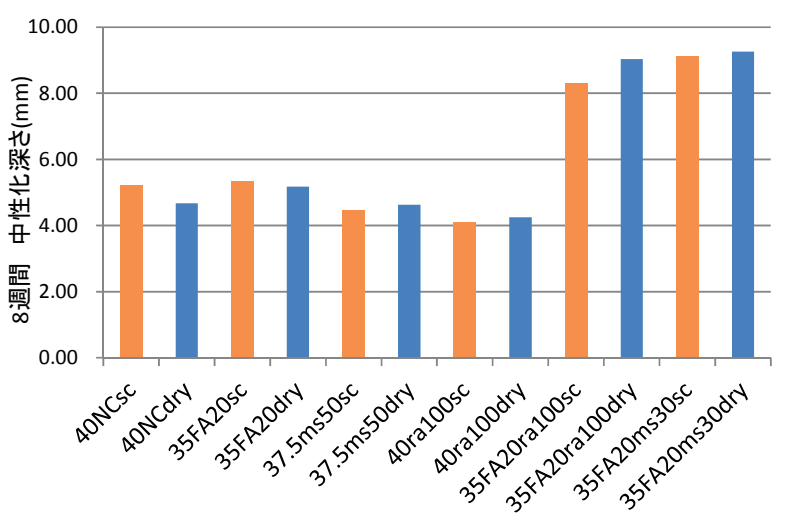

図-2 促進中性化試験結果

\section{表－9＼cjkstart再生骨材 $1 \mathrm{t}$ 製造時における環境負荷排出量}

\begin{tabular}{|c|c|c|c|}
\hline $\begin{array}{c}\mathrm{CO}_{2} \text { 排出量 } \\
\left(\mathrm{kg}-\mathrm{CO}_{2} / \mathrm{t}\right)\end{array}$ & $\begin{array}{c}\mathrm{SO}_{\text {X排出量 }} \\
\left(\mathrm{kg}-\mathrm{SO}_{\mathrm{X}} / \mathrm{t}\right)\end{array}$ & $\begin{array}{c}\mathrm{NO}_{\text {X排出量 }} \\
\left(\mathrm{kg}-\mathrm{NO}_{2} / \mathrm{t}\right)\end{array}$ & $\begin{array}{c}\text { ばいじん排出量 } \\
(\mathrm{kg}-\mathrm{PM} / \mathrm{t})\end{array}$ \\
\hline 10.1 & $4.9 . \mathrm{E}-03$ & $4.1 . \mathrm{E}-03$ & $4.5 . \mathrm{E}-03$ \\
\hline
\end{tabular}

\section{2 圧縮強度試験結果}

表－8 に材齢 7 日における圧縮強度試験結果を示す。表 -8のsc は打設後蒸気養生を行なった供試体を意味し, dry は打設後気中暴露した供試体を意味する。基本配合の出荷 強度は材齢 7 日で $35 \mathrm{~N} / \mathrm{mm}^{2}$ となっており, 全ての配合が出 荷強度を満足する結果となった。

\section{3 促進中性化試験結果}

打設後 1 週間気中暴露した後に, 温度 $20^{\circ} \mathrm{C}$, 相対湿度 $60 \%$, 二酸化炭素濃度 5\%の中性化促進環境に 8 週間保管するこ とで促進中性化試験を行なった。その結果を図ー2に示す。 基本配合に対してフライアッシュと溶融スラグ細骨材や再 生粗骨材を同時に置換した場合, 中性化深さが約 $3 \mathrm{~mm}$ 程 度大きくなる結果となった。また, 蒸気養生の有無により, 8 週間の促進中性化試験の結果ではあるが, 中性化深さに 顕著な相違は見られなかった。

\section{4 低環境負荷型 PCa の環境負荷評価}

上記の方法で $\mathrm{PCa}$ 製品の原材料を産業廃棄物や産業副産 物で置換し，気温の高い日に限り蒸気養生を行わない仮定 の下で環境負荷評価を行った。 1 年のうち平均気温が $25^{\circ} \mathrm{C}$ 以上の日を気温の高い日と想定し，PCa 製品製造の際に蒸 気養生を行わなくてもよいと仮定した。ヒアリング調査を 行なった $\mathrm{PCa}$ 製品製造会社近郊の過去 3 年の気温を調べた 結果，日平均気温が $25^{\circ} \mathrm{C}$ 超える日は 365 日中平均 64 日 であった。調査対象である $\mathrm{PCa}$ 製品会社の 1 年の操業日数 は261.5 日であることを考慮し，さらに，週 5 日操業であ るとすると, その内で蒸気養生を行わない日数が 45.7 日と なることから，蒸気養生を行う際の年間重油使用量を 45.7/261.5 低減できることとした。

また，環境負荷評価を行うにあたり，再生骨材製造時に 発生する環境負荷量を算出した。表一9に再生骨材 $1 \mathrm{t}$ 製造 時における環境負荷量の算出結果を示す。これは，再生骨 材製造時に発生する微粉末(以下, フィラー), 再生粗骨材, 再生細骨材の全量を $1 \mathrm{t}$ 製造する際に発生する環境負荷物 質排出量である。この結果は，本研究で使用した再生骨材 の製造にあたって使用された重機や破砕機の使用時間，燃 料消費量および電力消費量をもとに算出したものである。 低環境負荷型 PCa の環境負荷量は表－1，表－2，表－9 を もとに算出した。

図ー3に製品 $1 \mathrm{~m}^{3}$ 製造する際に排出される $\mathrm{CO}_{2}$ 排出量の 結果を示す。グラフ中の数值は排出量を示し，グラフ上部 の数值は基本配合に対する排出量の比を表している。また， 溶融スラグ細骨材を使用した 35FA20ms30 のグラフ上部に 示寸括弧内の数值は，溶融スラグ細骨材の環境負荷排出量 をゼロと見なした場合の環境負荷の比を意味する。図ー1 より $\mathrm{CO}_{2}$ 排出量の大部分は原材料起源が占めているため, 蒸気養生を行わない場合, 製品化起源の $\mathrm{CO}_{2}$ 排出量は約 $72 \%$ 低減となるものの, $\mathrm{PCa}$ 製品製造における $\mathrm{CO}_{2}$ 排出量 では約 $14 \%$ 低減となる。さらにセメントの $20 \%$ をフライ ッシュに，細骨材の $30 \%$ を溶融スラグ細骨材に置換するこ 


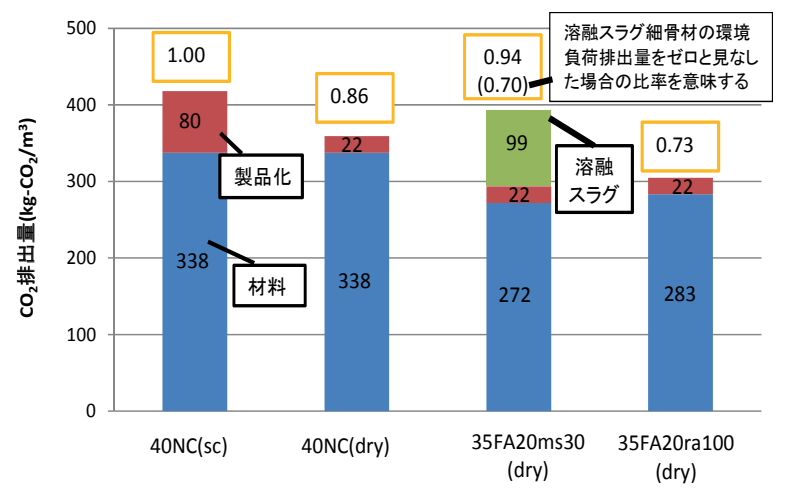

図ー3 $\mathrm{PCa}$ 製品 $1 \mathrm{~m}^{3}$ あたりの $\mathrm{CO}_{2}$ 排出量結果

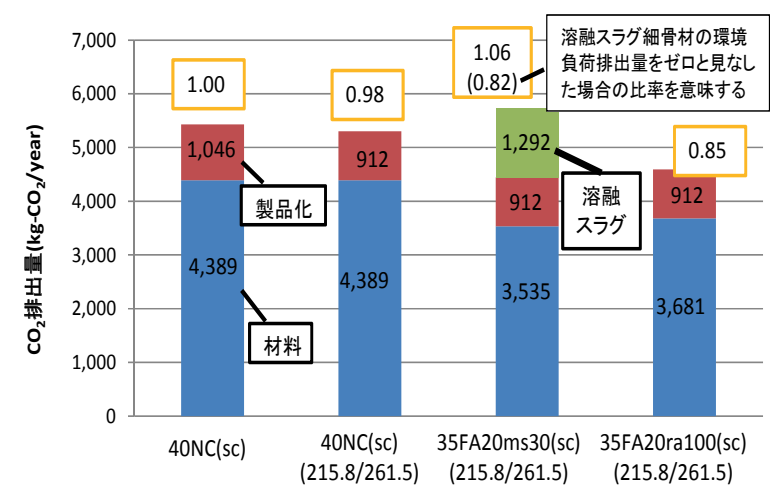

図-4 年間 $\mathrm{CO}_{2}$ 排出量結果

とで，原材料起源の $\mathrm{CO}_{2}$ 排出量は約 $19 \%$ 低减となり， $\mathrm{PCa}$ 製 品製造における $\mathrm{CO}_{2}$ 排出量は約 $30 \%$ 低減となる。なお，溶融 スラグ細骨材の製造において排出される環境負荷に関し，廃 棄物は溶融スラグ細骨材の製造の有無に関わらず减容化のた め溶融処理されるため, 環境負荷物質排出量として考慮しな (考え方がある 2)。そのため, 本研究では溶融スラグ細骨材 の製造により排出される環境負荷量は，その他の原材料製造 により排出される環境負荷量と区別して評価を行った。

図一 4 に $\mathrm{PCa}$ 製品製造における年間 $\mathrm{CO}_{2}$ 排出量を示す。グ ラフ下部の（215.8/261.5） とは, 日平均気温が $25^{\circ} \mathrm{C}$ 以上の日 は蒸気養生を行わないとするため, 重油使用量を 215.8/261.5 とした場合の結果であることを意味する。図ー4 より, $\mathrm{CO}_{2}$ 排出量は原材料起源が大部分を占めているため, 蒸気養生を 行わないことにより重油使用量を低減しても $\mathrm{CO}_{2}$ 排出量低減 にはあまり効果的でない結果となった。また, セメントの $20 \%$ をフライアッシュに, 細骨材の $30 \%$ を溶融スラグ細骨材に置 換することで $\mathrm{CO}_{2}$ 排出量を約 $18 \%$ 低減できる。 $\mathrm{NO}_{\mathrm{X}}$ 排出量の 算出結果は $\mathrm{CO}_{2}$ 排出量と同じ傾向を示し, セメントの $20 \%$ を フライアッシュに, 細骨材の $30 \%$ を溶融スラグ細骨材に置換 することで $\mathrm{NO}_{\mathrm{X}}$ 排出量を約 17\%低減できる結果となった。

図一5 製品 $1 \mathrm{~m}^{3}$ 製造する際に排出される $\mathrm{SO}_{\mathrm{X}}$ 排出量の結 果を示寸。図-1より $\mathrm{SO}_{\mathrm{X}}$ 排出量の大部分は製品化起源が占 めているため, 蒸気養生を行わないことで PCa 製品製造にお ける $\mathrm{SO}_{\mathrm{x}}$ 排出量は約 $79 \%$ の低減となる。また，セメントをフ ライアッシュに置換することでも $\mathrm{SO}_{\mathrm{X}}$ 排出量の低減効果はあ

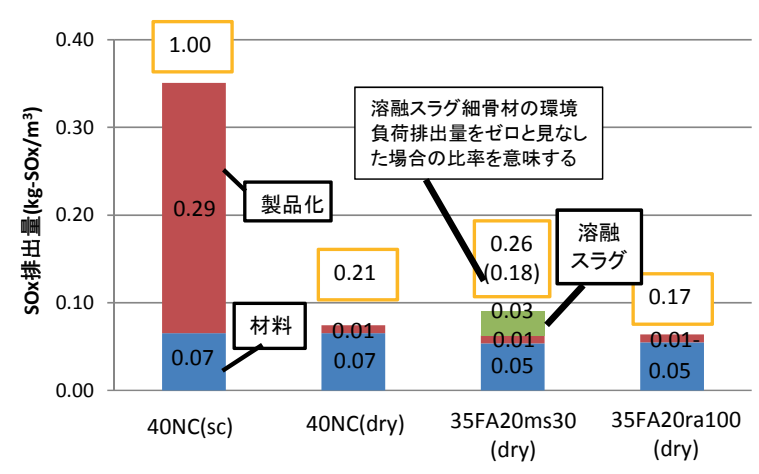

図ー5 $\mathrm{PCa}$ 製品 $1 \mathrm{~m}^{3}$ あたりの $\mathrm{SO}_{\mathrm{x}}$ 排出量結果

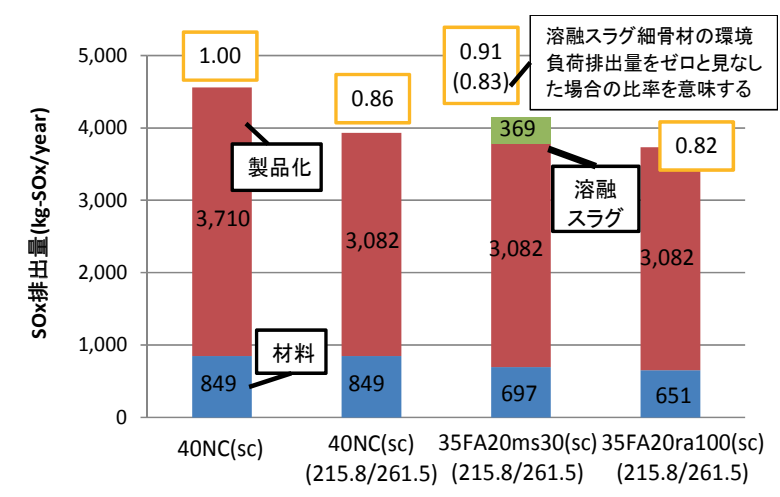

図一6 年間 $\mathrm{SO}_{\mathrm{x}}$ 排出量結果

るが，重油使用量を減らす方がより効果的であることは明ら かである。

図一6に $\mathrm{PCa}$ 製品製造における年間 $\mathrm{SO}_{\mathrm{X}}$ 排出量を示寸。図 -6より重油使用量を 215.8/261.5 (約 17\%低減)にすること で $\mathrm{SO}_{\mathrm{X}}$ 排出量は約 14\%低減でき，さらにセメントの $20 \%$ をフ ライアッシュに, 細骨材の $30 \%$ を溶融スラグ細骨材に置換す ることで $\mathrm{SO}_{\mathrm{X}}$ 排出量を約 17\%低减できる結果となった。ばい じん排出量の算出結果は $\mathrm{SO}_{\mathrm{X}}$ 排出量と同じ傾向を示し, 重油 使用量を215.8/261.5にすることでばいじん排出量を約 13\%低 減でき,さらにセメントと細骨材の置換を行うことでばいじ 几排出量を約 17\%低減できる結果となった。

以上, $\mathrm{PCa}$ 製品の原材料を産業廃棄物や産業副産物に置換 し, 気温の高い日に限り蒸気養生を行わない場合の $\mathrm{CO}_{2}, \mathrm{SO}_{\mathrm{X}}$, $\mathrm{NO}_{\mathrm{x}}$ およびばいじん排出量の評価を行った結果, フライアッ シュの使用によるセメント使用量の低減が $\mathrm{CO}_{2}$ 排出量と $\mathrm{NO}_{\mathrm{x}}$ 排出量の低減に効果的であり, 気温の高い日に限り蒸気 養生を行わないようにすることで重油使用量を低減すること が $\mathrm{SO}_{\mathrm{X}}$ 排出量とばいじん排出量の低減に効果的であった。

このことから, 本研究で扱った材料の範囲では, 以下の手 法を用いることが低環境負荷型 $\mathrm{PCa}$ の製造を可能にするとい える。

・所定材龄において所要の設計基淮強度を得られる範囲内 で，蒸気養生を省略する。

・水結合材比を $5 \%$ 低下させてセメントに対しフライアッ シュを20\%置換し, 細骨材の 30\%を溶融スラグ細骨材と 


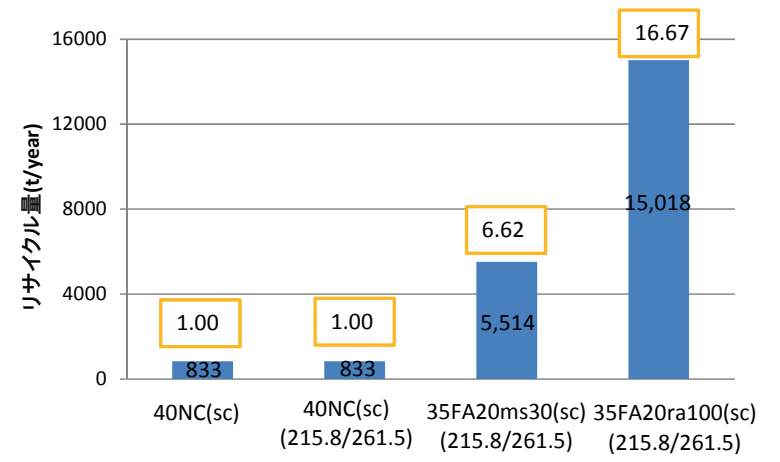

図一7＼cjkstart年間リサイクル量結果

表-10 各材料, 燃料のコスト

\begin{tabular}{|c|c|c|}
\hline 材料名 & 単位 $(*)$ & コスト $($ 円 $/ *)$ \\
\hline $\mathrm{C}$ & $\mathrm{t}$ & 9,600 \\
\hline $\mathrm{FA}$ & $\mathrm{t}$ & 6,400 \\
\hline $\mathrm{S}$ & $\mathrm{t}$ & 3,100 \\
\hline $\mathrm{ms}$ & $\mathrm{t}$ & 3,100 \\
\hline $\mathrm{G}$ & $\mathrm{t}$ & 2,600 \\
\hline $\mathrm{ra}$ & $\mathrm{t}$ & 2,600 \\
\hline $\mathrm{Ad}$ & $\mathrm{t}$ & 148,000 \\
\hline 重油 & $\mathrm{L}$ & 70 \\
\hline 軽油 & $\mathrm{L}$ & 125 \\
\hline 電力 & $\mathrm{kWh}$ & 20 \\
\hline
\end{tabular}

コスト欄の単位の分母 $(*)$ は, 各分類の単位欄に示す単位がその位 置に入ることを示す

置換する。

・水結合材比を 5\%低下させてセメントに対しフライア ッシュを $20 \%$ 置換し, 粗骨材の全量を再生粗骨材 M に 置換する。

一方，溶融スラグ細骨材や再生粗骨材を使用した場合， 細骨材や粗骨材使用で排出される環境負荷は少ないため, 環境負荷低減に効果的ではなかった。しかし，溶融スラグ 細骨材や再生粗骨材の使用は，廃棄物をコンクリート用材 料として再利用することにより, 廃棄物処分量の低減と砕 砂や砕石など天然資源の消費を抑制することが目的である。 そこで，ここでの産業副産物や廃棄物を処分する代わりに 再利用した量をリサイクル量として評価することを試みた。 リサイクル量は, フライアッシュ, 溶融スラグ細骨材, 再 生粗骨材およびセメントの使用によって発生するものとな る。表一1 より本研究で用いた環境負荷原単位では, フラ イアッシュはリサイクル量がないとなっているが，フライ アッシュも産業副産物であり使用するだけ廃棄物処分量を 低減できると考えられるため, フライアッシュが全て再利 用された場合を想定し, リサイクル量を $1000 \mathrm{wet}-\mathrm{kg} / \mathrm{t}$ と仮 定してリサイクル量を算出した。図ー7 にリサイクル量の 算出結果を示す。図ー7より, 砕砂使用量の $30 \%$ を溶融ス ラグ細骨材に置換することで 40NC の場合の約 7 倍, 砕石 を再生粗骨材に $100 \%$ 置換することで約 17 倍と, リサイク ル量は大きく増大する結果となった。

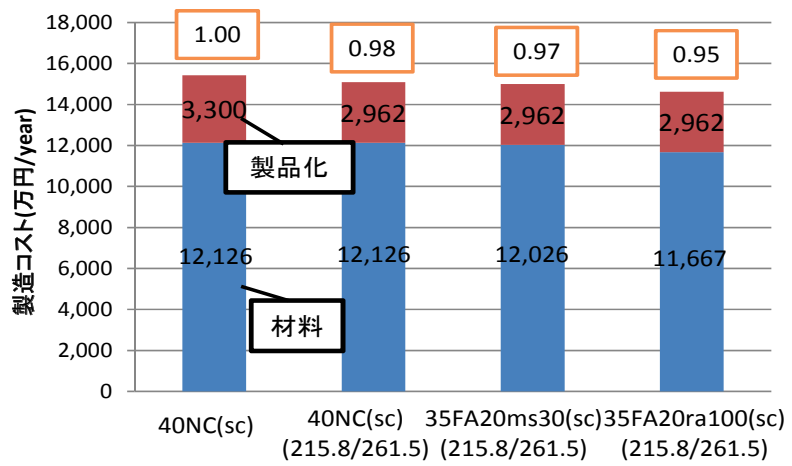

図ー8 コスト算出結果

\section{5 低環境負荷型 PCa のコスト面からの考察}

前節まででは，PCa 製品の環境負荷評価を行うことで環 境性能を明らかにし，環境性能向上方法を提案した。しか し, 一般的にコンクリート製品は力学性能とコストが重視 されるため, 環境負荷低減を図った PCa 製品に関しても, 力学性能とコストを無視することはできない。そこで, PCa 製品を製造する際のコストについての考察を行う。

表一10 に参考資料 ${ }^{3)}$ から引用した各材料, 燃料のコスト を示す。表一10 のコストはプラント持込み価格である。な お，溶融スラグ細骨材と再生粗骨材のコストは得ることが できなかったため, 溶融スラグ細骨材は砕砂と, 再生粗骨 材は砕石と同じ価格であると仮定した。コストは環境負荷 と同様に各材料や各燃料使用量に単価を乗じることで算出 した。図ー8に $\mathrm{PCa}$ 製品製造における年間コストの算出結 果を示す。製品化起源のコストは蒸気養生を行わないこと で重油使用量を低減でき，コストの低減となった。材料起 源のコストに関して，フライアッシュはセメントに比べて 值段が安いためコストの低減となるが，基本配合と同等の 強度レベルとするために水結合材比を低く設定した結果, 材料使用量, 混和剂使用量が多くなるのでコストの増大と なる。また溶融スラグ細骨材は砕砂に比べて密度が大きい ため置換の際に使用量が多くなりコストの増大になり，再 生粗骨材は砕石に比べて密度が小さいため置換の際に使用 量が少なくなりコストの低減となった。それらの要因によ って各配合のコストは上下し，その結果，本研究において 提案する低環境負荷型 $\mathrm{PCa}$ 製品では約 2 5\%程度のコスト 低減という結果となった。

\section{4. 高リサイクル型 PCa の検討}

\section{1 実験概要}

解体されたコンクリートの再利用率は 1995 年以降 $96 \%$ 以上と高い水準を維持しているが，用途の大半が再生路盤 材でありコンクリート用への再生骨材にはほとんど利用さ れていない。また，再生骨材製造時に大量に発生するフィ ラーは再利用の用途がなく現状廃棄されるのみであり, 廃 棄物処理場の観点からも問題となっている。一方で，この 
フィラーの主たる成分はセメントペーストであるため，水 分を与えることで再び水和反応を起こし硬化する可能性が 考えられる。

以上のことを踏まえ，天然骨材を再生骨材に，フィラー を結合材の一部に置換することで PCaにおける高リサイク ル化を図り，廃棄物処分量の低減と砕砂や砕石などの天然 資源の消費量削減を検討した。

ここでは，PCa の高リサイクル化を目指すため，コンク リートの解体時における, 再生骨材と再生骨材製造時に発 生するフィラーを含めた全量をリサイクルできるような配 合について検討した。すなわち，再生骨材製造時のフィラ 一, 再生粗骨材, 再生細骨材の質量比をそのままでコンク リートに使用することを検討した。表一11に再生骨材製造 時の再生粗骨材，再生細骨材の粒度別およびフィラーの質 量比を示す。また, 表一12 で示す PCa 製品製造会社の配合 を基本配合とし，その基本配合のうち高炉スラグ微粉末の 一部をフィラーに，粗骨材の一部を再生粗骨材に，細骨材 の一部を再生細骨材に置換した。本検討では, 環境負荷物 質排出量の低減を図る目的で, 表一3 に示した基本配合の 中で結合材を変更し, 普通ポルトランドセメントの一部を 高炉スラグ微粉末で置換し, 水結合材比を $40 \%$ から $36 \%$ に 低下させ，これを基本配合とした。ここで，普通ポルトラ ンドセメントではなく高炉スラグ微粉末の一部にフィラー を置換したのは，フィラーが硬化に寄与する程度が明確で はなく，普通ポルトランドセメントに置換した場合に大幅 な強度低下を生じる懸念があったためである。なお，フィ ラーと再生粗骨材，再生細骨材の比を変化させた配合につ

表-11 不要 PCa から製造される再生骨材の粒径別および フィラーの質量比

\begin{tabular}{|c|c|c|c|}
\hline 粒径範囲(mm) & \multicolumn{2}{|c|}{ 質量比率 } & フィラーに対する質量比 \\
\hline $20-13$ & $12 \%$ & \multirow{2}{*}{$42 \%$} & 0.75 \\
& $30 \%$ & & 1.88 \\
\hline $5-05$ & \multicolumn{2}{|c|}{$42 \%$} & 2.63 \\
\hline 微粒分(フィラー) & \multicolumn{2}{|c|}{$16 \%$} & 1.00 \\
\hline 計 & \multicolumn{2}{|c|}{$100 \%$} & - \\
\hline
\end{tabular}

いても検討した。これをフィラーの再利用率として表すこ ととし，例えば，フィラーの再利用率を $50 \%$ とした場合， コンクリートに利用する再生粗骨材と再生細骨材の量はそ れぞれ 2 倍とした。本研究で用いた再生骨材は，調查対象 とした PCa製品製造会社の不要コンクリート製品の一つを 破砕処理したものであり，配合は表－12のようになってい る。製造した再生骨材の品質は M (絶乾密度 $2.45 \mathrm{~g} / \mathrm{cm}^{2}$, 吸 水率 $3.47 \%$ ）であり, 得られたフィラーの密度は $2.42 \mathrm{~g} / \mathrm{cm}^{3}$ であった。検討を行った各種配合を表ー13に示す。表中の $36 \mathrm{NC}$ とは基本配合を示し，FL はフィラー，BF は高炉ス ラグ微粉末，RA は再生粗骨材，RS は再生細骨材をそれぞ れ示す。また, 配合名は最初の数值が水結合材比を示し, その後に基本配合に対するフィラーの置換率とフィラーの 再利用率を示している。

今回の検討では, 全ての供試体において蒸気養生を行っ た。蒸気養生の方法は，打設後 2 時間を前置き時間とし, その後昇温速度 $20^{\circ} \mathrm{C} / \mathrm{h}$ で昇温した後, $60^{\circ} \mathrm{C}$ 一定で 6 時間養 生し, 以降, 自然冷却とした。

硬化後のコンクリートに関しては, 圧縮強度試験, 促進 中性化試験および自由収縮の測定を行った。

\section{2 圧縮強度試験結果}

図－9 に材齢 7 日における圧縮強度試験結果を示す。円 柱供試体（ $\phi 100 \mathrm{~mm}$, 高さ 200mm）を作製し，蒸気養生を 行った後, 1 週間気中暴露した。基本配合の出荷強度は材 齢 7 日で $35 \mathrm{~N} / \mathrm{mm}^{2}$ である。一部の配合において材齢 7 日で $35 \mathrm{~N} / \mathrm{mm}^{2}$ に若干達しないものも見られたが，全ての配合で 概ね所要の強度を満足する結果が得られた。これは，本研 究で用いた再生骨材の原コンクリートの実強度が材齢 7 日 で $47.4 \mathrm{~N} / \mathrm{mm}^{2}$ と強度の高い $\mathrm{PCa}$ であり, 品質が良好であっ たことも一因であると考えられる。

表-12 PCa 製品会社の基本配合

\begin{tabular}{|c|c|c|c|c|c|c|c|c|c|}
\hline $\begin{array}{c}\text { 設計基準強度 } \\
\left(\mathrm{N} / \mathrm{mm}^{2}\right)\end{array}$ & \multirow{2}{*}{ W/B } & \multirow{2}{*}{ Air $(\%)$} & \multirow{2}{*}{$\mathrm{s} / \mathrm{a}$} & \multicolumn{6}{|c|}{ 単位量 $\left(\mathrm{kg} / \mathrm{m}^{3}\right)$} \\
\hline & & & & $W$ & $\mathrm{C}$ & $\mathrm{BF}$ & $\mathrm{S}$ & $\mathrm{G}$ & $\mathrm{Ad}$ \\
\hline 35.0 & 0.36 & 2.0 & 0.42 & 169 & 352 & 117 & 711 & 1028 & 2.67 \\
\hline
\end{tabular}

表ー13 環境負荷評価を行った各配合

\begin{tabular}{|c|c|c|c|c|c|c|c|c|c|c|c|c|c|c|}
\hline \multirow{2}{*}{ 配合名 } & \multirow{2}{*}{ W/B } & \multirow{2}{*}{ Air $(\%)$} & \multirow{2}{*}{$\mathrm{s} / \mathrm{a}$} & \multicolumn{11}{|c|}{ 単位量 $\left(\mathrm{kg} / \mathrm{m}^{3}\right)$} \\
\hline & & & & W & $c$ & $\mathrm{BF}$ & $S$ & G20-13 & G10-05 & $\mathrm{Ad}$ & $\mathrm{FL}$ & RA20-13 & RA13-05 & RS \\
\hline $36 \mathrm{NC}$ & 0.36 & 2.0 & 0.42 & 169 & 352 & 117 & 711 & 668 & 360 & 2.67 & 0 & 0 & 0 & 0 \\
\hline 33FL5FLR100 & 0.33 & 2.0 & 0.42 & 169 & 384 & 102 & 623 & 606 & 326 & 3.16 & 26 & 19 & 48 & 67 \\
\hline 30FL10FLR100 & 0.30 & 2.0 & 0.42 & 169 & 423 & 85 & 517 & 531 & 286 & 4.05 & 56 & 42 & 106 & 148 \\
\hline 32FL5FLR50 & 0.32 & 2.0 & 0.42 & 169 & 396 & 106 & 542 & 551 & 297 & 2.67 & 26 & 40 & 99 & 139 \\
\hline 31FL5FLR25 & 0.31 & 2.0 & 0.42 & 169 & 409 & 109 & 379 & 444 & 239 & 2.67 & 27 & 186 & 100 & 286 \\
\hline 33FL5FLR25 & 0.33 & 2.0 & 0.42 & 169 & 365 & 122 & 531 & 569 & 307 & 4.42 & 26 & 33 & 102 & 172 \\
\hline 27FL15FLR100 & 0.27 & 2.0 & 0.42 & 169 & 399 & 133 & 529 & 562 & 303 & 6.42 & 94 & 30 & 94 & 158 \\
\hline 36FL2.5FLR100 & 0.36 & 2.0 & 0.42 & 169 & 343 & 114 & 695 & 661 & 356 & 2.87 & 12 & 4 & 12 & 20 \\
\hline 29FL15FLR100 & 0.29 & 2.0 & 0.42 & 169 & 372 & 124 & 553 & 580 & 312 & 6.12 & 87 & 28 & 87 & 147 \\
\hline
\end{tabular}




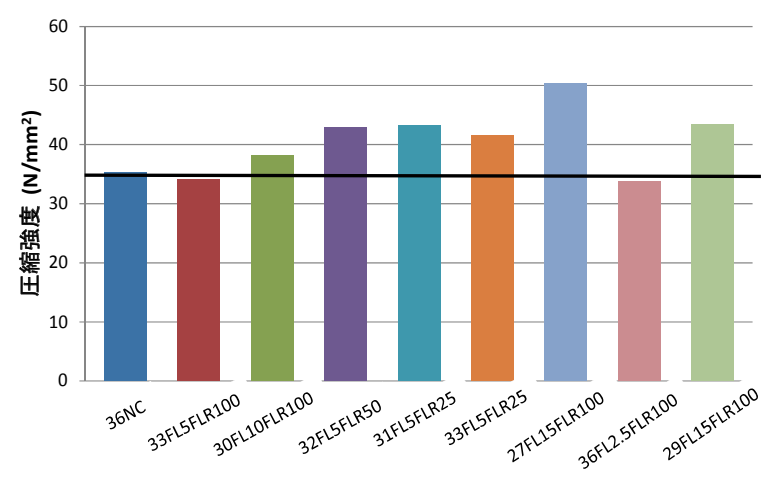

図－9＼cjkstart圧縮強度試験結果（材齢 7 日）

\section{3 促進中性化試験結果}

円柱供試体（ $\phi 100 \mathrm{~mm}$, 高さ $200 \mathrm{~mm})$ を作製し, 蒸気養 生を行った後, 1 週間気中暴露し, 温度 $20^{\circ} \mathrm{C}$, 相対湿度 $60 \%$, 二酸化炭素濃度 $5 \%$ の中性化促進環境に保管した。促進開 始後 4 週間, 8 週間で中性化促進環境から供試体を取り出 し割裂した後に, フェノールフタレイン溶液を吹き付け中 性化深さの測定を行なった。促進開始後 4 週から 8 週にか けて, 中性化深さの進展は見られたものの, それぞれの配 合での大小関係については同様の傾向を示したため, ここ では 8 週間促進中性化試験を実施した結果を図ー10 亿示す。 中性化促進環境に 8 週間置いた供試体のうち, 2 つの配 合で基本配合よりも中性化深さが大きい。特に，基本配合 に対してフィラーを $2.5 \%$ 置換, フィラーの再利用率を 100\%とした配合（36FL2.5FLR100）においては，中性化促 進環境 8 週目において中性化深さが $36 \mathrm{NC}$ より $2 \mathrm{~mm}$ ほど大 きくなる結果となった。他の配合では, フィラーや再生骨 材の置換率を大きくするほど水結合材比を小さくしたため, セメント硬化体が緻密になり中性化の促進が遅れたと考え られるが，36FL2.5FLR100 においては，基本配合と同じ水 結合材比でフィラーや再生骨材を置換したため, セメント 硬化体の組織が粗になり中性化が促進されたものと考える。 また， 2 つの配合以外では，基本配合よりも中性化深さが 小さくなり, $\mathrm{PCa}$ 製品としての耐久性は十分に有寸るもの が得られると判断する。

\section{4 自由収縮測定結果}

角柱供試体 $(100 \mathrm{~mm} \times 100 \mathrm{~mm} \times 400 \mathrm{~mm})$ を作製し，打設 後蒸気養生を行い, 材齢 1 日で脱型し, コンタクトチップ を $30 \mathrm{~cm}$ の間隔で 2 面に付け, コンタクトゲージを用いて 自由収縮の測定を行った。測定中の供試体は, 温度 $20^{\circ} \mathrm{C}$, 相対湿度 $60 \%$ の室内にて気中暴露した。測定結果を図一11 に示す。いずれの供試体においても, 基本配合 $(36 \mathrm{NC})$ よ り収縮量が大きくなる結果となった。材齢 60 日では, 特に $\mathrm{W} / \mathrm{B}=33 \%$ ，フィラーを $5 \%$ 置換，フィラーの再利用率を 100\%とした配合（33FL5FLR100）において基本配合よりも $200 \mu$ ほど大きな収縮となった。また，ここに記載していな い他の配合に関しても，同様に基本配合よりも収縮量が大 きくなる結果となっている。これは, 再生骨材の周りに付

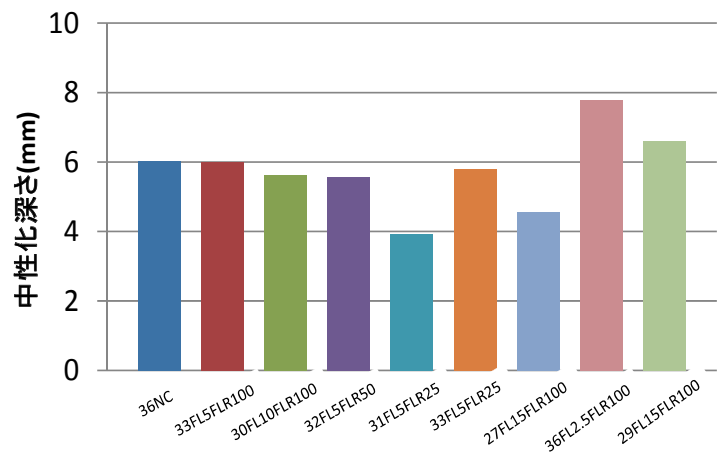

図-10 促進中性化試験結果（8 週目）

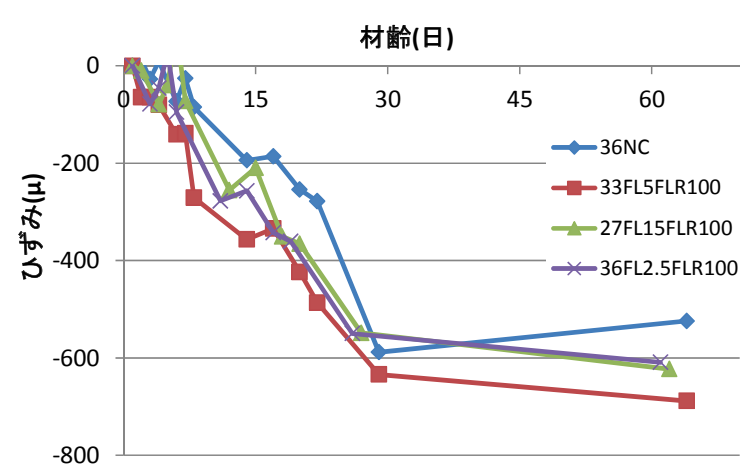

図-11 自由収縮測定結果

着したモルタル分の影響で天然骨材よりも吸水率が大きく なったことが原因であると考えられるが，高リサイクル型 PCa の配合では硬化後のコンクリートの体積変化に注意を 要する結果となった。

\section{5 高リサイクル型 PCa の環境負荷評価}

3.4 と同様の方法により高リサイクル型 PCa 環境負荷 評価を行った。使用したインベントリデータは表ー1, 表一 2，表一9に示寸ものである。環境負荷評価を行った配合の 結果の一部を図ー12〜図ー15 示す。グラフ中の数值はそ れぞれの排出量を示し, グラフ上部の数值は基本配合 （36NC）に対する排出量の比を示している。PCa の高リサ イクル化を図ることで，いずれの配合においても基本配合 より環境負荷量は多少大きくなる結果となった。これは, 再生骨材製造における重機や破砕機の使用によって重油や 軽油，電力の使用量が増大したことによるものである。ま た, $\mathrm{CO}_{2}$ 排出量と $\mathrm{NOx}$ 排出量では原材料起源の排出量の方 が製品化起源の排出量よりも大きくなり，SOx 排出量とば いじん排出量では製品化起源の排出量の方が原材料起源の 排出量よりも大きくなった。これは, 蒸気養生を行う際に 大量に使用される重油の影響によるものである。

次に, 高リサイクル型 PCa では, 高リサイクル化による 廃衰物処分量の低減と砕砂や砕石などの天然資源の消費を 抑制することを目的とすることから，産業副産物や産業廃 棄物を処分する代わりに再利用した量をリサイクル量とし 

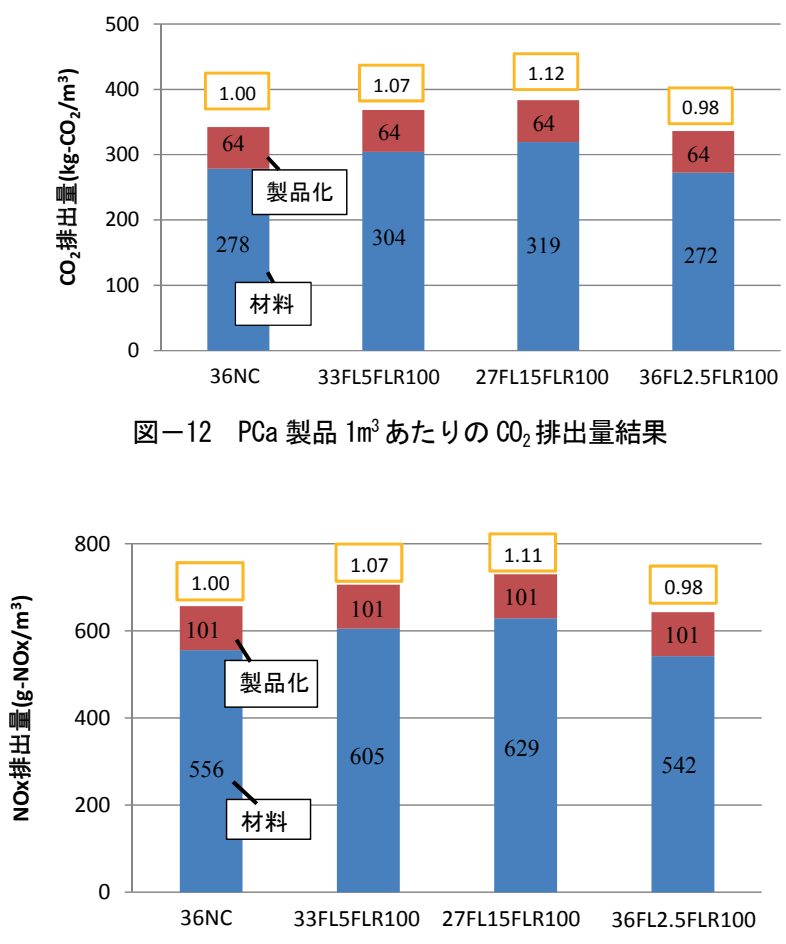

図ー14 PCa 製品 $1 \mathrm{~m}^{3}$ あたりの N0x 排出量結果

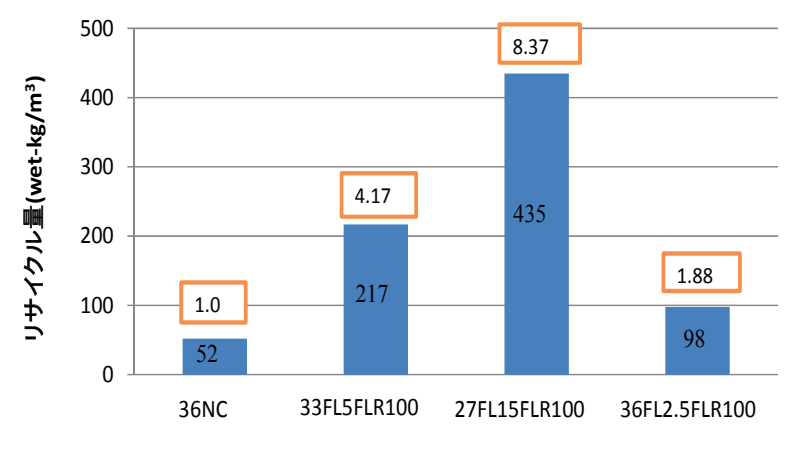

図ー16 PCa 製品 $1 \mathrm{~m}^{3}$ あたりのリサイクル量

て評価を行った。ここでのリサイクル量は, 再生粗骨材, 再生細骨材, フィラーおよびセメントの使用によって発生 する。図ー16に PCa 製品 $1 \mathrm{~m}^{3}$ あたりのリサイクル量の算出 結果を示す。グラフ中の数值はそれぞれリサイクル量を示 し, グラフ上の数值は基本配合に対するリサイクル量の比 を表している。

図ー 16 より, W/B $=33 \%$, フィラーを $5 \%$ 置換して再利用 率を 100\%とした配合（33FL5FLR100）においてはリサイ クル量が基本配合の約 4 倍に, W/B $=27 \%$, フィラーを $15 \%$ 置換して再利用率を $100 \%$ とした配合（27FL15FLR100）に おいてはリサイクル量が約 8 倍に増大寸る結果となった。

上述した環境負荷物質排出量では配合により大きな差異 はなかったものの, リサイクル量の増加率は基本配合に比 べて非常に大きくなる結果となった。このことから, 硬化 後のコンクリートの体積変化には留意を要するものの,

PCa にフィラーや再生骨材を材料として使用することで行 う PCaの高リサイクル化は環境負荷低減の観点から見ると 非常に有意義であると考えられる。特に, PCa 製品製造工 場において, 種々の理由で不要となった $\mathrm{PCa}$ 製品を廃棄す
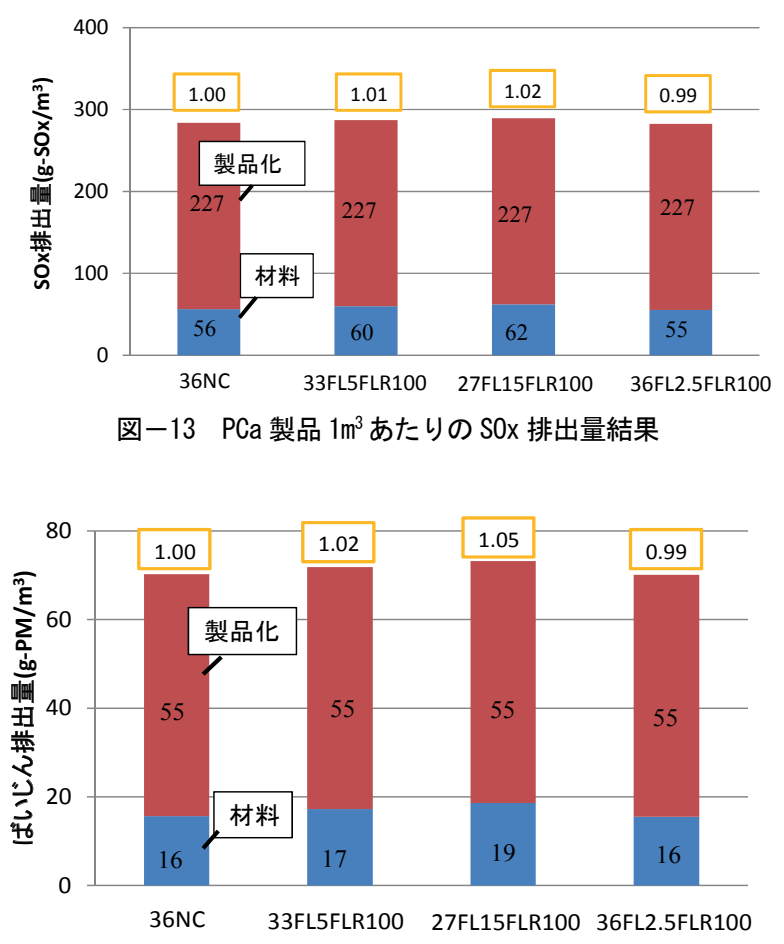

図ー15 PCa 製品 $1 \mathrm{~m}^{3}$ あたりのばいじん排出量結果

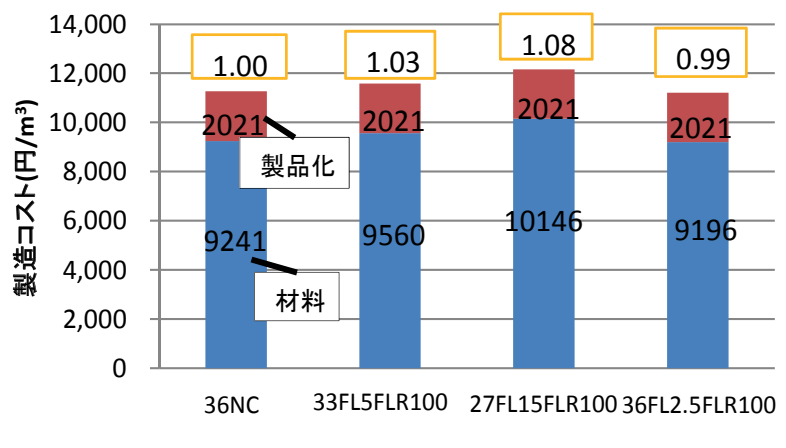

図ー17 コスト算出結果

るのではなく，それらから製造されるフィラーや再生骨材 を材料として活用することは，PCa 製品製造会社のゼロエ ミッション化へもつながり，資源循環を行ううえでの意義 は大きいものと思われる。

\section{6 コスト面からの考察}

3.5 と同様に, コスト面からの考察を行った。各材料, 各燃料のコストは, 3.5 と同様に参考資料 ${ }^{3}$ から引用した。 ただし, 高炉スラグ微粉末のコストは得られなかったため, 対象とした PCa製品会社からヒアリング調查で得られたも のを使用し，再生骨材のコストは砕石と同じであると仮定 した。また，フィラーに関しては産業副産物であるとみな し価格を 0 と仮定した。コストは, 環境負荷量と同様に各 材料や各燃料使用量に単価を乗じることで算出した。図一 17 にC 製品製造におけるコストの算出結果を示す。

ほとんどの配合で基本配合よりもコストが大きくなって しまう結果となった。これは, 基本配合と同等の強度レ心゙ ルとするために水結合材比を低く設定した結果，材料使用 量, 混和剂使用量が多くなってしまったことで, コストの 増大につながってしまったと考えられる。 


\section{5. まとめ}

本研究では，低環境負荷型 $\mathrm{PCa}$ 製品と高リサイクル型 $\mathrm{PCa}$ 製品の提案とそれに伴う力学性能の評価および環境負 荷評価を行った。これらの結果から明らかになった事項に ついて下に示す。

1) $\mathrm{PCa}$ 製品製造における $\mathrm{CO}_{2}$ 排出量と $\mathrm{NO}_{\mathrm{X}}$ 排出量はそ れぞれ全体の約 $81 \%$ と約 $84 \%$ が原材料起源で排出さ れ, $\mathrm{SO}_{\mathrm{X}}$ 排出量とばいじん排出量はそれぞれ約 $81 \%$ と 約 79\%が製品化起源で排出される。

2) 1 年のうち 45.7 日間蒸気養生を行わないことで $\mathrm{SO}_{\mathrm{X}}$ 排 出量とばいじん排出量低減に効果的であり, それぞれ 約 $14 \%$ ，約 $13 \%$ の低減となる。

3）蒸気養生の回数を減らした上でセメントの $20 \%$ をフ ライアッシュに, 細骨材の $30 \%$ を溶融スラグ細骨材に 置換することで $\mathrm{CO}_{2}$ 排出量と $\mathrm{NO}_{\mathrm{X}}$ 排出量低減に効果 的でありそれぞれ約 18\%，約 17\%の低減となる。

4) $\mathrm{PCa}$ 製品を製造する際の砕砂の $30 \%$ を溶融スラグ細骨 材に，砕石の $100 \%$ を再生粗骨材に置換することでリ サイクル量はそれぞれ約 7 倍, 約 17 倍の増大となる。

5) PCa 製品の高リサイクル化を図ることで，PCa 製品製
造における $\mathrm{CO}_{2}$ 排出量と $\mathrm{SOx}$ 排出量が若干の増加傾 向を示すが, NOx 排出量とばいじん排出量については ほとんど変化がない。

6) PCa 製品の高リサイクル化を図ることでリサイクル量 が増大し，フィラーを結合材に 5\%置換，リサイクル 率を $100 \%$ とするとリサイクル量は約 4 倍に，また， フィラーを結合材に $2.5 \%$ 置換，リサイクル率を $100 \%$ とするとリサイクル量は約 2 倍になった。

1) 土木学会 : コンクリートの環境負荷評価（その2)，コンクリート技術 シリーズ 62, pp.39-40, 2004.9

2) 社団法人産業環境管理協会 : LCA 概論, LCA シリーズ, pp.86-93, 2007.11

3) 財団法人建設物価調査会 : 建設物価, 2008.10

Study on Measures for the Reduction of the Environmental Impact of Precast Concrete By Kenji Kawai, Akihiro Fujiki, Daiki Akasaki and Youichi Tokuhisa

Concrete Research and Technology, Vol.25, 2014

Synopsis: Although, in the design of a structure, structural and durability performance is considered, environmental performance such as $\mathrm{CO}_{2}$ emissions is rarely considered. This study investigated measures for the reduction of the environmental impact of precast concrete production through the use of industrial waste, industrial byproducts and recycled aggregates as well as omitting steam curing on hot days. It was found that SOx emissions can be reduced by about $14 \%$ by not performing stream curing for 45.7 days in a year, and that $\mathrm{CO}_{2}$ emissions can be reduced by about $18 \%$ by replacing $20 \%$ of ordinary portland cement with fly ash and $30 \%$ of fine aggregate with molten-slag fine aggregate.

Keywords: Environmental Impact, Precast Concrete, Recycled Aggregate, Steam Curing 